DOI: 10.46340/eppd.2020.7.4.9

Anastasiia Holishevska

ORCID ID: https://orcid.org/0000-0003-4593-3093

National Pedagogical Dragomanov University, Ukraine

\title{
TRUST AS A FUNDAMENTAL VALUE OF FORMING POLITICAL REPUTATION
}

\author{
Анастасія Голішевська

\section{ДОВІРА ЯК ФУНДАМЕНТАЛЬНА ЦННІСТЬ ФОРМУВАННЯ ПОЛІТИЧНОЇ РЕПУТАЦІЇ}

Національний педагогічний університет імені М.П. Драгоманова, Україна

\begin{abstract}
The article analyzes the factors influencing the formation of the level of trust as one of the main values of political reputation. Based on the results of sociological research, the priorities of trust of the citizens of Ukraine have been identified. The necessity of ensuring the stabilization of the political sphere and the progressive development of society through the establishment of social consolidation, political responsibility and the development of democratic forms of cooperation in the context of creating a positive political reputation is substantiated. Ways to restore the level of trust of Ukrainian citizens in socio-political institutions and the formation of a positive political reputation in the development of a democratic Ukrainian society has been identified.

Keywords: reputation, political reputation, trust, reputational development, reputational profile of the subject.
\end{abstract}

Репутація в сучасному світі перетворюється на популярний індикатор діяльності окремих політиків, організацій, органів влади, міст, територій та держав. Однією з важливих причин такої ситуації $\epsilon$ те, що встановлені формальні процедури створення демократичної влади не $\epsilon$ достатніми для іiї успішної діяльності. Регулярне проведення виборів, встановлення плюралізму суспільнополітичних відносин не гарантують позитивного розвитку суспільства, а часто приводять лише до дестабілізації, розповсюдження популізму та інших імітаційних технологій демократичного політичного управління. Замість формалізованих на перший план виходять неформальні, суб'єктивні чинники політичної діяльності, що викликає необхідність формування та цілеспрямованого управління репутацією суб’єктів політичної діяльності, ії постійного моніторингу та оцінки.

Необхідною умовою створення позитивної політичної репутації є довіра громадян до органів політичної влади. Довіра створює зв'язок публічних інститутів з громадянами, формує почуття спільності інтересів та цілей діяльності.

Проблемі довіри присвячено багато праць науковців, що вивчають соціальні відносини та обмін, засади суспільно-політичного ладу та встановлення органічної солідарності між людьми (Е.Гідденс, Е.Дюркгейм, Н.Луман, Дж. Колеман, Т.Парсонс, Р.Патнам, Ф.Тьоніс, Ф.Фукуяма, П.Штомпка та ін.). В той же час, недостатньо вивченими залишаються сучасні чинники та проблеми формування політичної репутації шляхом встановлення довіри до влади як раціонального інструменту створення стабільної політичної системи суспільства.

Політична репутація представляє собою усвідомлену колективну оцінку громадянами поведінки, якостей і результатів діяльності суб'єкта політики, рівень очікувань та довіри до нього як у внутрішньому, так і зовнішньому середовищі. Саме репутація та «верифікація» іiі результату довіра, часто відіграють вирішальну роль в суспільно-політичних трансформаціях XXI сторіччя. Значення даного феномену описав Ф.Фукуяма. Вчений зазначав, що «...стабільна політична структура... може виникнути лише за умов, якщо люди, що об'єднані спільними інтересами, здатні до співробітництва заради загальних цілей - здатність заснована, в кінцевому випадку, на довірі» ${ }^{1}$ Зрозуміло, що недовіра та негативна репутація виступають суттєвим бар'єром на шляху демократичної самоорганізації суспільства.

\footnotetext{
${ }^{1}$ Фукуяма, Ф. (2004). Доверие: соичиальные добродетели. Москва: ООО «Издательство АСТЗАО НПП «Ермак», 580.
} 
Для осягнення сучасних аспектів формування та розвитку довіри велике значення мають висновки Е.Гідденса, який виділяв персоніфіковану довіру, що побудована на міжособистісних зобов'язаннях та анонімну довіру до абстрактних систем ${ }^{1}$. Саме анонімна довіра, на думку вченого, актуалізується в сучасну епоху, де виключну роль відіграють суспільні інститути та символічнознакові системи. П.Штомпка вважав, що виняткове значення для процесів демократичної трансформації суспільства має формування «культури довіри», основними напрямками становлення якої виступають: структурні можливості заохочення довіри та готовність і бажання суб'єктів використовувати дані ресурси ${ }^{2}$. Довіра як основа функціонування суспільства розглядається в працях Дж. Колемана та Р.Д. Патнама. Вони визначають довіру як базову засаду формування соціального капіталу, «мережу інституціоналізованих зв'язків або відносин, цілеспрямовано сформованих у вигляді зобов'язань і очікувань, інформаційних каналів та інших соціальних норм» ${ }^{3}$.

Таким чином, у загальному вимірі виділяють три різновиди суспільної довіри:

- довіра між людьми як принцип життєвої поведінки;

- довіра до близьких (родичів, друзів, колег по роботі);

- довіра до інститутів державної влади, політичних лідерів, партій, рухів, політичних рішень та дій влади, тобто інституціоналізована форма ${ }^{4}$.

Відповідно, довіра у політичній сфері є результатом функціонування політичних інститутів. Вона виступає як підтримка, позитивна оцінка суспільством діяльності органів влади, політичних організацій та окремих політиків (зовнішній вимір), а також передбачувана, побудована на соціальних чеснотах поведінка політичних акторів у відносинах один з одним (внутрішній вимір).

Хоча значна частина дослідників розглядають довіру як непередбачуваний культурний феномен, що важко піддається цілеспрямованим впливам, існує думка, що вона може бути також і результатом вдалого управління, ${ }^{5,6}$ Саме під впливом такого управління формується інституціоналізована довіра як основа легітимності діяльності органів влади. Інституціоналізована довіра «означає підтримку органів державної влади, а також неурядових інституцій (бізнесу, ЗМI, профспілок і т.д.), які відіграють ключову роль у генеруванні та виконанні громадських «правил гри» та забезпечують функціональність «інструментів демократії» (виборів, різноманітних форм політичної та громадської участі тощо)» ${ }^{7}$.

Формування інституціоналізованої довіри виступає значною проблемою в українському суспільстві. Як визначає О.Новакова, «для українського суспільства проблема формування довіри до влади ускладнюється негативним історичним контекстом, коли влада завжди була «чужа», ворожа, насильницька, i, відповідно, не заслуговувала на підтримку. Україна позбулася колоніального статусу, але влада досі так і не стала «своєю», про що свідчать як соціологічні дослідження рівня легітимності основних інститутів влади, так і форми боротьби українців за свої права».

Важливою проблемою виступає визначення чинників, що впливають на рівень довіри до державних органів та політичних інститутів в Україні. Оскільки головною причиною недовіри виступає корумпованість органів влади та їх нездатність вирішувати проблеми, то головним фактором відновлення довіри виступає встановлення прозорості та відкритості в роботі органів державної влади, організація їх діяльності на принципах законності та соціальної справедливості. Невипадково, оцінюючи результати реформування суспільства за 2019 рік, серед чотирьох головних проблем, що найбільше гальмують розвиток України громадяни назвали корупцію (69\% опитаних) та відсутність професіоналів у владі (25\%). В той же час позитивно оцінили дії влади у подоланні корупції лише $9,8 \%$ громадян, а у підвищенні якості чиновницького апарату лише $5,5 \%$.

\footnotetext{
${ }^{1}$ Giddens, A. (1990). The consequences of modernity. Stanford univ. press.

${ }^{2}$ Sztompka, P. (1991). Society in action: the theory of social becoming. Cambridge: Polity Press, 211.

${ }^{3}$ Coleman, J.S. (1988). Social Capital in the Creation of Human Capital. American Journal of Sociology, 94-120.

${ }^{4}$ Головаха, Е., Костенко, Н., Макеев, С. (ред.) (2014). Общество без доверия. Киев: Институт социологии НАН Украины, 155-156.

${ }^{5}$ Thompson, M. (1998). Trust, Motivation and Commitment. Strategic Remuneration Research Centre, 66-71.

${ }^{6}$ Greenberg, J. (1993). A taxonomy of organizational justice theories. Academy of Management Journal, 12, 9-22.

7 Зеленько, Г.І. (2018). Подолання кризи інституиійної довіри як передумова розвитку соиіального капіталу. Київ: ІПіЕНД НАН України, 38-65.

${ }^{8}$ Новакова, О.В. (2019). Комунікативні аспекти формування довіри до влади в українському суспільстві. Науковий часопис НПУ імені МП Драгоманова, 22, (26), 31-36.

${ }^{9}$ Реформи в Україні: громадська думка населення 2019. Дослідження Фонду «Демократичні ініціативи» імені Ілька Кучеріва. <https://dif.org.ua/article/reformi-v-ukraini-gromadska-dumka-naselennya-2019>.
} 
Опитування регіональних експертів та журналістів, що проводилося з Фондом «Демократичні ініціативи» імені Ілька Кучеріва $з 8$ по 15 травня 2020 року, однією $з$ провідних проблем останніх президентів України (Петра Порошенка та Володимира Зеленського) виявило провальну кадрову політику. 77 журналістів, політичних експертів та громадських активістів із різних регіонів України оцінили іï у 2,1 бали з 10 можливих ${ }^{1}$.

Неефективність системи підготовки та підбору керівних кадрів відбивається в тому, що близько половини громадян $(48,3 \%)$ не бачать ніяких результатів реформ. Лише $22,2 \%$ спостерігають як позитивні, так і негативні наслідки реформаторської діяльності влади. При цьому, тільки 2,4\% зазначають, що задоволені даним процесом, а $22,6 \%$ опитаних висловили протилежну позицію ${ }^{2}$. Про низький рівень відкритості та прозорості в функціонуванні органів влади свідчить те, що лише $19 \%$ населення задоволена рівнем інформування про реформаторські зусилля державних органів, що формує невірну оцінку їх діяльності в суспільстві, створює підгрунтя для популізму та політичної безвідповідальності ${ }^{3}$.

Таким чином, провідною проблемою продукування довіри до органів влади в українському суспільстві є ослаблення функцій держави та слабкість рівноправної, відкритої, системної комунікації з громадянським суспільством. Довіра до інститутів влади в Україні є у загальному вимірі низькою непостійною та фрагментарною. Їй притаманні сплески «надії» та швидке розчарування. Така ситуація пов' язана, зокрема, з історичним минулим, тривалими періодами бездержавності, коли влада була чужою, ототожнювалася з загарбниками та колонізаторами. В Україні склався соціальний досвід, що для виживання в суспільстві впродовж тривалого історичного часу ефективною була недовіра, тому зміни в даному аспекті здійснюються дуже повільно. На жаль, за майже 30 років незалежного існування ситуація мало в чому змінилася. Після періодів потужних суспільних протестів формувалася короткочасна авансована довіра до політичних лідерів та сил, але, оскільки переможці не конвертували підтримку в результативний політичний розвиток, все закінчувалося лише поглибленням відчуження громадян та соціальною апатією.

Такі висновки підтверджують і показники розвитку актуальної політичної ситуації. Після гучної перемоги Володимира Зеленського на президентських виборах з 70,3\% підтримки громадян та суттєвою перевагою в усіх областях України, окрім Львівської, українці продемонстрували черговий підйом довіри до інститутів та лідерів політичної влади. Достатньо високу підтримку мали також і провідні соціально-політичні інститути, що видно з наступної таблиці.

Дані таблиці яскраво ілюструють пріоритети довіри громадян України. По-перше, вони полягають в персоніфікації влади і ототожненні іï зглавою держави, саме від нього очікують вирішення актуальних суспільних проблем. По-друге, тривалі періоди слабкості та неефективності державних інститутів привчили українців самостійно в неформальній площині досягати життєвих цілей, тому на другому місці розташовується підтримка волонтерських організації. I, по-третє, військова агресія Росії, втрата частини території, довготривалий військовий конфлікт на Донбасі створили в країни атмосферу напруження та очікування небезпеки, відповідно лідерами довіри стали Збройні Сили України, Національна гвардія та Державна служба надзвичайних ситуацій. В той же час, достатню високу підтримку мали уряд та парламент (57\%), особливо у порівнянні 3 періодом напередодні виборів 2019 року, коли рейтинг довіри громадян до інститутів влади набув від'ємних значень: президент (-46\%); Верховна Рада (-69\%); уряд (-55\%)

Не менш інформативними є дані щодо лідерів недовіри, серед яких назване дослідження виявило судову систему (рівень недовіри $72 \%$ ), місцеві суди (66\%), політичні партії (63\%), Верховний Суд (59\%), Конституційний суд $(59 \%)$, чиновники (55\%). Таким чином, найголовнішою

\footnotetext{
${ }^{1}$ Перший рік Президента Зеленського: опитування журналістів та експертів у регіонах. Опитування Фонду «Демократичні ініиіативи» імені Ілька Кучеріва (2020). <https://dif.org.ua/article/pershiy-rik-prezidenta-zelenskogoopituvannya-zhurnalistiv-ta-ekspertiv-u-regionakh?fbclid=IwAR2Jgxyp7rW2WOeRykJEc0HYahmUMCwff7apEL7_ K8tT2T_JvS6x69htAjk>.

${ }^{2}$ Національне опитування щодо громадського залучення (2020). Фонд «Демократичні ініціативи» імені Ілька Кучеріва. $<$ https://dif.org.ua/article/ukraintsi-zalucheni-do-gromadskoi-diyalnosti-ale-unikayut-aktivnoi-uchasti> . ${ }^{3}$ Перший рік Президента Зеленського: опитування журналістів та експертів у регіонах. Опитування Фонду «Демократичні інічіативи» імені Ілька Кучеріва. <https://dif.org.ua/article/pershiy-rik-prezidenta-zelenskogoopituvannya-zhurnalistiv-ta-ekspertiv-u-regionakh?fbclid=IwAR2Jgxyp7rW2WOeRykJEc0HYahmUMCwff7apEL7_ K8tT2T_JvS6x69htAjk>.

${ }^{4}$ Бондаренко, П. (2019). Ставлення українців до реформ: куди поділася «зрада»? Фонд "Демократичні ініціативи" ім. Ілька Кучеріва. <https://dif.org.ua/article/stavlennya-ukraintsiv-do-reform-kudi-podilasya-zrada> .
} 
Рівень довіри до соціально-політичних інститутів після президентських та парламентських виборів 2019 року в Україні

\begin{tabular}{|l|c|}
\hline \multicolumn{1}{|c|}{ Соціально-політичний інститут } & Рівень довіри (\%) \\
\hline Президент України & 79 \\
\hline Збройні Сили України & 74 \\
\hline Волонтерські організації & 69 \\
\hline Державна служба надзвичайних ситуацій & 64 \\
\hline Національна гвардія України & 64 \\
\hline Церква & 63 \\
\hline Уряд України & 57 \\
\hline Верховна Рада України & 57 \\
\hline ЗМІ України & 56 \\
\hline Громадські організації & 52 \\
\hline Національна поліція & 51 \\
\hline
\end{tabular}

*Таблицю складено автором за результатами опитування Украӥнського иенттру економічних $i$ політичних досліджень імені Олександра Разумкова ${ }^{l}$.

проблемою довіри, а відповідно і репутації влади, $\epsilon$ нездатність створених інститутів права захистити громадян, створити чіткі, діючи норми соціально-політичної поведінки, які б розповсюджувалися на усіх членів суспільства.

Подивимося тепер, як змінилася ситуація по визначених позиціях за декілька місяців шляхом аналізу даних такого самого дослідження Центру імені Олександра Разумкова за лютий 2020 року.

Переважно лідери довіри зберегли свої позиції в сфері безпеки та громадянських асоціацій: Збройні Сили України - 69\% підтримки; Державна служба з надзвичайних ситуацій - 65\%; Церква $62,5 \%$; Волонтерські організації - 60\%; Національна гвардія України - 60\%; ЗМІ України - 52,5\%.

Щодо недовіри, то тут на перше місце вийшов державний апарат (чиновники) - їм недовіряють $77 \%$ опитаних, потім традиційно іде судова система - 76\%; політичні партії - 70\%; Верховний Суд $64 \%$; Антикорупційний Суд - 64\%; Конституційний суд $-60,5 \%{ }^{2}$.

Таким чином спостерігаємо, що у загальному вимірі усі інститути, яким довіряють українці, втратили по декілька відсотків підтримки, а лідери недовіри, навпаки, ще погіршили свою суспільну оцінку.

Найбільше втратили довіру українців інститути політичної влади, включаючи і Президента, який, хоча і зберіг позитивний рейтинг, втратив за декілька місяців майже $20 \%$ підтримки.

Причинами падіння довіри стали:

- низька ефективність діяльності влади (37\% опитаних вважають, що влада не намагається вирішити проблеми розвитку країни, а лише імітує активну діяльність);

- невиконання обіцянок та очікувань громадян (20\% респондентів заявили, що нова влада не виправдала їх сподівань, 19\% відповіли, що від нової влади вони нічого доброго не очікували, і це підтвердилося, а 13\% заявили, що влада навіть перевершила їх найгірші побоювання;

- зосередженість влади на приватних інтересах замість загальнонаціональних. 37\% опитаних вважали, що дії Президента В.Зеленського в першу чергу спрямовані на захист загальнонаціональних інтересів, а з 24,5\% до $41 \%$ зросла частка респондентів, вважали, що діяльність Президента В.Зеленського спрямована, передусім, на захист власних інтересів та інтересів наближених до нього ${ }^{3}$.

\footnotetext{
${ }^{1}$ Оцінка громадянами ситуації в країні та діяльності влади (2019). Центр Разумкова.

$<$ http://razumkov.org.ua/napriamky/sotsiologichni-doslidzhennia/otsinka-gromadianamy-sytuatsii-v-krainita-diialnosti-vlady>.

${ }^{2}$ Оцінка громадянами діяльності влади, рівень довіри до соціальних інститутів та політиків, електоральні орієнтації громадян (2020). Центр Разумкова. <razumkov.org.ua/napriamky/sotsiologichni-doslidzhennia/ otsinka-gromadianamy-diialnosti-vlady-riven-dov $>$.

3 Там само.
} 
Таблиця 2

Рейтинг довіри до політичних інститутів в Україні (лютий 2020)

\begin{tabular}{|l|c|c|c|}
\hline \multicolumn{1}{|c|}{ Політичний інститут } & Довіра (\%) & Недовіра (\%) & Рейтинг \\
\hline Президент України & 51,5 & 41 & $+10,5$ \\
\hline Верховна Рада України & 28 & 65 & -37 \\
\hline Уряд України & 28 & 64,5 & $-36,5$ \\
\hline Політичні партії & 17 & 70 & -54 \\
\hline
\end{tabular}

*Таблицю складено автором за результатами опитування Украӥнського иентру економічних і політичних досліджень імені Олександра Разумкова ${ }^{1}$

Ще більше загострилася ситуація під впливом світової пандемії COVID-19 та загального карантину, що привело, за свідченнями експертів, до суттєвого погіршення соціально-політичного клімату в регіонах та негативних оцінок діяльності суб'єктів владних повноважень та державних установ і закладів. Розповсюдження зневіри та деструктивних настроїв серед громадян може привести не тільки до чергового погіршення репутації влади, але й створити підгрунтя для масових протестів як з соціальними, так і політичними вимогами. У загальному вимірі експерти порівняно низько оцінили ефективність Володимира Зеленського на посаді Президента України з середньою оцінкою його діяльності лише у 3,1 бала за 10 бальною шкалою ${ }^{2}$.

I хоча думка експертів відрізняється від загальних оцінок населення діяльності Президента Зеленського, вона $\epsilon$ своєрідним маркером тенденцій, що вже формуються в громадянському суспільстві, і повинна враховуватися при розробці стратегій та програм діяльності та підтримки позитивної репутації як центральної, так і регіональної влади.

Таким чином, в сучасному українському суспільстві знов починає створюватися негативна репутація влади на основі низької довіри громадян до соціально-політичних інститутів, що викликається як реальними результатами їх діяльності, так і загальною атмосферою тривоги та незахищеності. Це, в свою чергу, створює підгрунтя для соціальної напруги, кризових ситуацій та інших деструктивних соціальних явищ. Упередження даних негативних явищ та забезпечення стабільного розвитку суспільства потребує підсилення прозорості та ефективності політичних рішень, розвитку системи громадського контролю за їх реалізацією на практиці, формування чіткої підзвітності влади та відповідальності за результати запровадження суспільно-політичних програм. Для створення та зміцнення позитивної репутації влади необхідно побудувати міцні партнерські відносини з громадянами, коли довіра буде формуватися на грунті спільної діяльності і суспільство об'єднається не навкруги критики державних інститутів, а за рахунок колективних зусиль у напрямку вирішення актуальних проблем.

\section{References:}

1. Bondarenko, P. (2019). Stavlennia ukraintsiv do reform: kudy podilasia «zrada»? [Attitudes of Ukrainians to reforms: where has the "betrayal" gone?]. Fond "Demokratychni initsiatyvy" im. Ilka Kucheriva [Democratic Initiatives Foundation Ilka Kucheriva]. <https://dif.org.ua/article/stavlennya-ukraintsiv-do-reform-kudi-podilasya-zrada $>$. [in Ukrainian].

2. Holovakha, E., Kostenko, N., Makeev, S. (ed.) (2014). Obshchestvo bez doveryia [A society without trust]. Kyiv: Ynstytut sotsyolohyy NAN Ukrayny, 155-156.

3. Zelenko, H.I. (2018). Podolannia kryzy instytutsiinoi doviry yak peredumova rozvytku sotsialnoho kapitalu [Overcoming the crisis of institutional trust as a prerequisite for the development of social capital]. Kyiv: IPiEND NAN Ukrainy, 38-65. [in Ukrainian].

4. Natsionalne opytuvannia shchodo hromadskoho zaluchennia (2020) [National survey on public involvement]. Fond «Demokratychni initsiatyvy» imeni Ilka Kucheriva [Ilko Kucheriv Democratic Initiatives Foundation].

\footnotetext{
${ }^{1}$ Оцінка громадянами діяльності влади, рівень довіри до соціальних інститутів та політиків, електоральні орієнтації громадян (2020). Центр Разумкова. <razumkov.org.ua/napriamky/sotsiologichni-doslidzhennia/otsinkagromadianamy-diialnosti-vlady-riven-dov>.

${ }^{2}$ Перший рік Президента Зеленського: опитування журналістів та експертів у регіонах (2020).

$<$ https://dif.org.ua/article/pershiy-rik-prezidenta-zelenskogo-opituvannya-zhurnalistiv-ta-ekspertiv-u regionakh

?fbclid=IwAR2Jgxyp7rW2WOeRykJEc0HYahmUMCwff7apEL7_K8tT2T_JvS6x69htAjk>.
} 
$<$ https://dif.org.ua/article/ukraintsi-zalucheni-do-gromadskoi-diyalnosti-ale-unikayut-aktivnoi-uchasti>. [in Ukrainian].

5. Novakova, O.V. (2019). Komunikatyvni aspekty formuvannia doviry do vlady v ukrainskomu suspilstvi [Communicative aspects of building trust in government in Ukrainian society]. Naukovyi chasopys NPU imeni MP Drahomanova [Scientific journal of NPU named after MP Drahomanov], no. 22, (26), 31-36. [in Ukrainian].

6. Otsinka hromadianamy diialnosti vlady, riven doviry do sotsialnykh instytutiv ta politykiv, elektoralni oriientatsii hromadian (2020) [Citizens assessment of government activities, the level of trust in social institutions and politicians, electoral orientations of citizens]. Tsentr Razumkova [Razumkov Center].

<razumkov.org.ua/napriamky/sotsiologichni-doslidzhennia/otsinka-gromadianamy-diialnosti-vlady-riven-dov>.

7. Otsinka hromadianamy sytuatsii v kraini ta diialnosti vlady (2019) [Citizens assessment of the situation in the country and the activities of the government]. Tsentr Razumkova [Razumkov Center].

$<$ http://razumkov.org.ua/napriamky/sotsiologichni-doslidzhennia/otsinka-gromadianamy-sytuatsii-v-krainita-diialnosti-vlady>. [in Ukrainian].

8. Pershyi rik Prezydenta Zelenskoho: opytuvannia zhurnalistiv ta ekspertiv u rehionakh [The first year of President Zelensky: a survey of journalists and experts in the regions]. Opytuvannia Fondu «Demokratychni initsiatyvy» imeni Ilka Kucheriva (2020) [The poll Fund "Democratic initiatives" Ilko Kucheriv].

$<$ https://dif.org.ua/article/pershiy-rik-prezidenta-zelenskogo-opituvannya-zhurnalistiv-ta-ekspertivu-regionakh?fbclid=IwAR2Jgxyp7rW2WOeRykJEc0HYahmUMCwff7apEL7_K8tT2T_JvS6x69htAjk>. [in Ukrainian].

9. Reformy v Ukraini: hromadska dumka naselennia 2019 [Reforms in Ukraine: public opinion]. Doslidzhennia Fondu «Demokratychni initsiatyvy» imeni Ilka Kucheriva [Research of the Ilko Kucheriv Democratic Initiatives Foundation]. <https://dif.org.ua/article/reformi-v-ukraini-gromadska-dumka-naselennya-2019>. [in Ukrainian].

10. Fukuiama, F. (2004). Doverye: sotsyalnye dobrodetely [Trust: social virtues]. Moscow: OOO «Yzdatelstvo ASTZAO NPP «Ermak». [in Russian].

11. Coleman, J.S. (1988). Social Capital in the Creation of Human Capital. American Journal of Sociology, 94-120. [in English].

12. Giddens, A. (1990). The consequences of modernity. Stanford univ. press. [in English].

13. Greenberg, J. (1993). A taxonomy of organizational justice theories. Academy of Management Journal, no. 12, 9-22. [in English].

14. Sztompka, P. (1991). Society in action: the theory of social becoming. Cambridge: Polity Press. [in English].

15. Thompson, M. (1998). Trust, Motivation and Commitment. Strategic Remuneration Research Centre. [in English]. 